\title{
Distribution of lead and silver under lead blast furnace conditions ${ }^{(*)}$
}

\author{
M. Pérez*, A. Romero*, A. Hernández*, I. Almaguer** y R. Benavides**
}

\begin{abstract}
Two experimental studies of metal solubility in slags were carried out at $1473 \mathrm{~K}\left(1200^{\circ} \mathrm{C}\right)$. In the first one the solubility of lead in the $\mathrm{PbO}-\mathrm{ZnO}-\mathrm{CaO}-\mathrm{SiO}_{2}-" \mathrm{Fe}_{2} \mathrm{O}_{3}$ " slag system under a reducing atmosphere $\left(\mathrm{P}_{\mathrm{CO}} / \mathrm{P}_{\mathrm{CO}}=2.45\right)$ was studied. In the second part, slags of the $\mathrm{CaO}-\mathrm{SiO}_{2}-" \mathrm{Fe}_{2} \mathrm{O}_{3}$ " system were equilibrated with $\mathrm{Pb}-1.3$ mass \% $\mathrm{Ag}$ alloys under an inert atmosphere. In both cases the $\mathrm{CaO} / \mathrm{SiO}_{2}$ mass ratio was from 1.0 to 1.6 and $\mathrm{Fe} / \mathrm{SiO}_{2}$ mass ratio was 1.1 and 1.7 . The lead solubility in the slags of both experimental parts diminishes with increasing the slag basicity $\left(\mathrm{CaO} / \mathrm{SiO}_{2}\right)$ and diminishing the $\mathrm{Fe} / \mathrm{SiO}_{2}$ ratio. Lead oxide is the only compound that can be reduced under the reducing atmosphere and at the temperature at the tuyeres level, $1473 \mathrm{~K}$. Silver solubility in slags decreases with increasing both $\mathrm{CaO} / \mathrm{SiO}_{2}$ and $\mathrm{Fe} / \mathrm{SiO}_{2}$ ratios in the slags of the $\mathrm{CaO}-\mathrm{SiO}_{2}-" \mathrm{Fe}_{2} \mathrm{O}_{3}$ " system.
\end{abstract}

\section{Distribución de plomo y plata bajo las condiciones del horno alto para la producción de plomo}

\begin{abstract}
Resumen
Se realizaron dos estudios experimentales de solubilidad de metal en escorias a $1.473 \mathrm{~K}\left(1.200^{\circ} \mathrm{C}\right)$. En el primero se estudió la solubilidad de plomo en el sistema $\mathrm{PbO}-\mathrm{ZnO}-\mathrm{CaO}-\mathrm{SiO}_{2}-" \mathrm{Fe}_{2} \mathrm{O}_{3}$ " bajo una atmósfera reductora $\left(\mathrm{P}_{\mathrm{CO}} / \mathrm{P}_{\mathrm{CO} 2}=2,45\right)$. En la segunda parte, escorias del sistema $\mathrm{CaO}-\mathrm{SiO}_{2}-" \mathrm{Fe}_{2} \mathrm{O}_{3}$ " fueron equilibradas con aleaciones $\mathrm{Pb}-1,3 \% \mathrm{Ag}$ en atmósfera inerte. En ambos casos la relación $\mathrm{CaO} / \mathrm{SiO}_{2}$ fue variada de 1.0 a 1.6 y la relación $\mathrm{Fe} / \mathrm{SiO}_{2}$ fue de 1,1 y 1,7 . La solubilidad de plomo en las escorias de ambas etapas experimentales disminuye con el incremento de la basicidad $\left(\mathrm{CaO} / \mathrm{SiO}_{2}\right)$ y la disminución de la relación $\mathrm{Fe} / \mathrm{SiO}_{2}$. El óxido de plomo es el único compuesto que puede ser reducido bajo la atmósfera reductora y a la temperatura en el nivel de las toberas del horno alto, $1.473 \mathrm{~K}$. La solubilidad de la plata en la escoria decrece con el aumento de las relaciones $\mathrm{CaO} / \mathrm{SiO}_{2}$ y $\mathrm{Fe} / \mathrm{SiO}_{2}$ en las escorias del sistema $\mathrm{CaO}-\mathrm{SiO}_{2}-\mathrm{Fe}_{2} \mathrm{O}_{3}$ ".
\end{abstract}

Palabras claves

Escoria; Plomo; Plata; Horno alto; Solubilidad.

\section{INTRODUCTION}

The primary production of lead metal is currently undertaken using lead blast furnaces ${ }^{[1}$ and 2$]$. The reduction of lead oxide in this furnace produces slags in the multicomponent system $\mathrm{PbO}-\mathrm{ZnO}-\mathrm{CaO}-\mathrm{SiO}_{2}-" \mathrm{Fe}_{2} \mathrm{O}_{3}$ "[3 and 4] which represents the major components of lead/zinc smelting slags in oxidizing conditions. The main factors that determine lead and lead oxide solubility in the slags have been a subject of theoretical and experimental researches ${ }^{[5}$ and 6$]$. Such studies have importance not only in limiting production losses of lead bullion, but also in minimizing the potencially hazardous waste material. Recent environmental restrictions on the disposal of solid waste have resulted in increasing pressure to lower the lead content of the slag.

Tan and $\mathrm{Vix}{ }^{[5]}$ developed a thermodynamic model for the reaction zone of lead blast furnace to predict the distribution of lead and zinc among slag, lead bullion, matte and gas and validated the model against plant data. Schlesinger and Lynch ${ }^{[7]}$ equilibrated molten $\mathrm{Pb}$ and $\mathrm{Pb}-\mathrm{Ag}$ alloy with slags of the $\mathrm{PbO}-\mathrm{CaO}-\mathrm{FeO}-\mathrm{Fe}_{2} \mathrm{O}_{3}-\mathrm{SiO}_{2}$ system at $1473 \mathrm{~K}$. They found that the solubility of lead oxide in the slag was directly proportional to the ferric/ferrous ratio, but decreased with increasing the $\mathrm{CaO} / \mathrm{SiO}_{2}$

(•) Trabajo recibido el día 20 de septiembre de 2011 y aceptado en su forma final el día 11 de abril de 2012.

* Metallurgy and Materials Department, IPN-ESIQIE, UPALM Ed.7, Zacatenco, México D.F., C.P. 07738, Mexico

** Servicios Administrativos Peñoles S.A. de C.V. Prol. Comonfort Sur 2050, Col. L. Echeverría, Torreón, C.P. 27300, Coahuila, Mexico- 
ratio. Kudo et al ${ }^{[8]}$, carried out experiments to determine the equilibria between $\mathrm{FeO}-\mathrm{CaO}-\mathrm{SiO}_{2}$ slags and lead metal in iron crucibles at temperatures from 1473 to $1573 \mathrm{~K}$, where they found that the highest lead solubility was obtained in the silicasaturated slag, while the lowest solubility was observed in the $\mathrm{CaO}$-saturated slags. Henao et a ${ }^{[9]}$, studied the indium and germanium distribution between lead bullion and slag of the $\mathrm{PbO}-\mathrm{FeO}-\mathrm{Fe}_{2} \mathrm{O}_{3}-\mathrm{CaO}-\mathrm{SiO}_{2}$ system.

Several works ${ }^{[10}$ and 11$]$ have been carried out to measure the gas composition, temperature and pressure within a commercial lead blast furnace. These works reported the concentrations of $\mathrm{CO}(\mathrm{g})$ and $\mathrm{CO}_{2}(\mathrm{~g})$ and temperatures profiles. It was shown that at the tuyeres level the temperature was about $1473 \mathrm{~K}\left(1200^{\circ} \mathrm{C}\right)$ and the $\mathrm{CO} / \mathrm{CO}_{2}$ volume ratio was between 2 and 2.5. The recovery of silver during lead metal extraction has the potential to add value to existing pyrometallurgical operations; however, few experimental data are available that describe the partitioning of silver between the lead bullion and the slag at the industrial process conditions.

The present study has been carried out in two parts. The aim of the first part is to provide information on the mineralogical species formed in the slags of the $\mathrm{PbO}-\mathrm{ZnO}-\mathrm{CaO}-\mathrm{SiO}_{2}-" \mathrm{Fe}_{2} \mathrm{O}_{3}$ " system at $1473 \mathrm{~K}$, under a reducing atmosphere $\left(\mathrm{P}_{\mathrm{CO}} / \mathrm{P}_{\mathrm{CO} 2}=2.45\right)$, and estimate the effect of the $\mathrm{CaO} / \mathrm{SiO}_{2}$ and $\mathrm{Fe} / \mathrm{SiO}_{2}$ mass ratios on the lead oxide solubility in the slags. The second part has as objective to equilibrate slags of the $\mathrm{CaO}-\mathrm{SiO}_{2}-" \mathrm{Fe}_{2} \mathrm{O}_{3}$ " system with a $\mathrm{Pb}-1.3$ mass $\% \mathrm{Ag}$ alloy at $1473 \mathrm{~K}$, under an inert atmosphere, and estimate the effect of the $\mathrm{CaO} / \mathrm{SiO}_{2}$ and
$\mathrm{Fe} / \mathrm{SiO}_{2}$ ratios on the lead and silver losses in the slag.

\section{EXPERIMENTAL PROCEDURE}

\subsection{First experimental part (Slags A)}

The experimental design is based on the typical sinter compositions used in mexican industrial blast furnaces, which includes the $\mathrm{PbO}-\mathrm{ZnO}-\mathrm{CaO}-\mathrm{SiO}_{2}$ " $\mathrm{Fe}_{2} \mathrm{O}_{3}$ " slag system with $\mathrm{CaO} / \mathrm{SiO}_{2}$ mass ratio from 1.0 to $1.6 ; \mathrm{Fe} / \mathrm{SiO}_{2}$ mass ratio of 1.1 and 1.7 and 40 mass \% $\mathrm{PbO}$ and $8 \% \mathrm{ZnO}$. Pure oxide powders ( $>99.5 \%$ ) were used as starting materials to prepare the synthetic slags. Master slags with the required amounts of $\mathrm{PbO}$ and $\mathrm{SiO}_{2}$ were firstly prepared to reduce the losses of lead species by vaporization. The master slags were then mixed with appropriate addition of the other pure oxide powders $(\mathrm{ZnO}, \mathrm{CaO}$ and $\mathrm{Fe}_{2} \mathrm{O}_{3}$ ) to prepare the final mixtures compositions given in table $\mathrm{I}$.

The samples were homogenized and equilibrated during $4 \mathrm{~h}$ in platinum crucibles at $1473 \mathrm{~K}$. The atmosphere within the reaction tube was maintained at a fixed oxygen partial pressure using $\mathrm{P}_{\mathrm{CO}} / \mathrm{P}_{\mathrm{CO} 2}=2.45\left(\mathrm{P}_{\mathrm{O} 2}=10^{-11.8}\right.$ atm at $\left.1473 \mathrm{~K}\right)$. After the equilibrium was reached, the crucible was pulled out of the hot zone of the furnace and quenched rapidly by jetting argon gas. The furnace temperature was controlled within $\pm 3 \mathrm{~K}$ with an $\mathrm{R}$-type thermocouple (Pt-Pt, $13 \% \mathrm{Rh})$. The slags were characterized by X-ray diffraction (XRD Bruker D8 Focus) to determine the mineralogical species. The microstructural and microanalysis were carried out

Table I. Composition of the slags used in the first experimental part in reducing atmosphere at $1473 \mathrm{~K}$ (mass \%)

Tabla I. Composición de las escorias usadas en la primera parte experimental en atmósfera reductora a $1.473 \mathrm{~K}$ (\% masa)

\begin{tabular}{lccccccc}
\hline Slag & $\mathrm{CaO}_{\mathbf{S i O}}$ & $\mathrm{Fe} / \mathrm{SiO}_{2}$ & $\mathrm{CaO}$ & $\mathrm{SiO}_{2}$ & $\mathrm{Fe}_{2} \mathrm{O}_{3}$ & $\mathrm{PbO}$ & $\mathrm{ZnO}$ \\
\hline A-1 & 1.0 & 1.1 & 14.55 & 14.55 & 22.89 & 40.0 & 8.0 \\
A-2 & 1.0 & 1.7 & 11.74 & 11.74 & 28.53 & 40.0 & 8.0 \\
A-3 & 1.2 & 1.1 & 16.54 & 13.78 & 21.68 & 40.0 & 8.0 \\
A-4 & 1.2 & 1.7 & 13.48 & 11.23 & 27.29 & 40.0 & 8.0 \\
A-5 & 1.4 & 1.1 & 18.33 & 13.09 & 20.59 & 40.0 & 8.0 \\
A-6 & 1.4 & 1.7 & 15.07 & 10.76 & 26.16 & 40.0 & 8.0 \\
A-7 & 1.6 & 1.1 & 19.94 & 12.46 & 19.60 & 40.0 & 8.0 \\
A-8 & 1.6 & 1.7 & 16.54 & 10.34 & 25.12 & 40.0 & 8.0
\end{tabular}




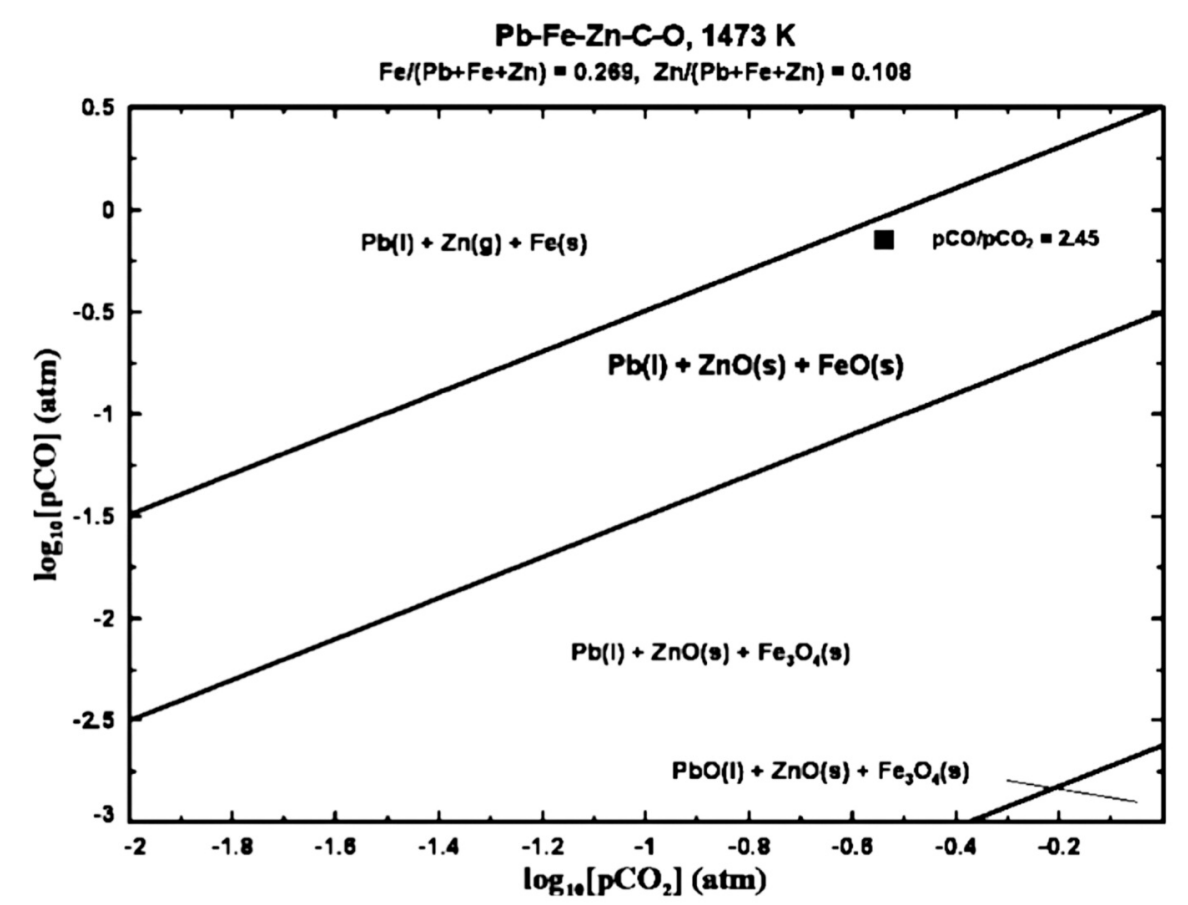

Figure 1. Calculated predominance area diagram for the $\mathrm{Pb}-\mathrm{Fe}-\mathrm{Zn}-\mathrm{C}-\mathrm{O}$ system at $1473 \mathrm{~K}$.

Figura 1. Diagrama de área de predominio calculado para el sistema $\mathrm{Pb}-\mathrm{Fe}-\mathrm{Zn}-\mathrm{C}-\mathrm{O}$ a $1.473 \mathrm{~K}$.

using scanning electron microscopy, FEI Quanta 600, EDAX EDS. Special care was taken in preparing the slag for the XRD and chemical analysis to ensure that the physically entrained lead particles were separated from the glassy slag sample.

\subsection{Second experimental part (Slags B)}

These experiments were carried out in a tubular resistance furnace using $15 \mathrm{~g}$ of $\mathrm{Pb}-\mathrm{Ag}$ alloy $(1.3$ mass $\% \mathrm{Ag}$ ) and $10 \mathrm{~g}$ of slags of the $\mathrm{CaO}-\mathrm{SiO}_{2}-" \mathrm{Fe}_{2} \mathrm{O}_{3}$ " system with $\mathrm{CaO} / \mathrm{SiO}_{2}=1.0$ to 1.6 and $\mathrm{Fe} / \mathrm{SiO}_{2}=1.1$ and 1.7. Table II shows the slag composition prepared in this experimental part of the $\mathrm{CaO}-\mathrm{SiO}_{2}-" \mathrm{Fe}_{2} \mathrm{O}_{3}$ " system.

The heating temperatures were chosen to obtain liquid slags: $1473 \mathrm{~K}$ for the slags with $\mathrm{CaO} / \mathrm{SiO}_{2}=1.0$ and 1.2 and $1573 \mathrm{~K}$ for the slags with $\mathrm{CaO} / \mathrm{SiO}_{2}=1.4$ and 1.6. The samples were equilibrated during $4 \mathrm{~h}$ in crucibles of low carbon steel under an inert atmosphere of argon with a flow of $150 \mathrm{ml} / \mathrm{min}$. After the equilibrium was reached, the crucible was pulled out of the hot zone of the furnace and quenched rapidly by jetting argon gas, and prepared for the
XRD, MEB and chemical analysis. Lead and silver contents in the slags were determined by atomic absorption analysis.

\section{RESULTS AND DISCUSION}

\subsection{First experimental part}

\subsubsection{Predominance area diagram}

The FACTSage thermodynamic software ${ }^{[12]}$ was used to estimate the $\mathrm{Pb}-\mathrm{Fe}-\mathrm{Zn}-\mathrm{C}$-O predominance area diagram at $1473 \mathrm{~K}$ to get an estimation of the prevailing phases in the blast furnace process, assuming that all condensed phases are pure substances. It is worth noting that a predominance area diagram is not a phase diagram since do not consider the formation of chemical solutions. Figure 1 shows the calculated diagram for slag A-1 with $\mathrm{CaO} / \mathrm{SiO}_{2}=1.0$ and $\mathrm{Fe} / \mathrm{SiO}_{2}=1.1$, which gives the molar ratios $\mathrm{Fe} /(\mathrm{Pb}+\mathrm{Fe}+\mathrm{Zn})=0.269$, $\mathrm{Zn} /(\mathrm{Pb}+\mathrm{Fe}+\mathrm{Zn})=0.108$. This figure shows that, under the reducing atmosphere $\left(\mathrm{P}_{\mathrm{CO}} / \mathrm{P}_{\mathrm{CO} 2}=2.45\right)$, the prevailing phases at $1473 \mathrm{~K}$ are $\mathrm{Pb}(1), \mathrm{ZnO}(\mathrm{s})$ 
Table II. Composition of the slags used in the second experimental part in inert atmosphere at $1473 \mathrm{~K}$ and $1573 \mathrm{~K}$ (mass \%)

Tabla II. Composición de las escorias usadas en la segunda parte experimental en atmósfera inerte a $1.473 \mathrm{~K}$ y $1.573 \mathrm{~K}$ (\% masa)

\begin{tabular}{lccccc}
\hline Slag & $\mathrm{CaO}_{\mathbf{S i O}}$ & $\mathrm{Fe}_{\mathbf{S}} \mathrm{SiO}_{2}$ & $\mathrm{CaO}$ & $\mathrm{SiO}_{\mathbf{2}}$ & $\mathrm{Fe}_{\mathbf{2}} \mathbf{O}_{3}$ \\
\hline B-1 & 1.0 & 1.1 & 27.99 & 27.99 & 44.02 \\
B-2 & 1.0 & 1.7 & 22.57 & 22.57 & 54.86 \\
B-3 & 1.2 & 1.1 & 31.81 & 26.50 & 41.69 \\
B-4 & 1.2 & 1.7 & 25.92 & 21.60 & 52.48 \\
B-5 & 1.4 & 1.1 & 35.24 & 25.17 & 39.59 \\
B-6 & 1.4 & 1.7 & 28.98 & 20.69 & 50.33 \\
B-7 & 1.6 & 1.1 & 38.35 & 23.96 & 37.69 \\
B-8 & 1.6 & 1.7 & 31.81 & 19.88 & 48.31 \\
\hline
\end{tabular}

and $\mathrm{FeO}(\mathrm{s})$; this means that $\mathrm{PbO}$ is the only oxide that it is reduced under the given process parameters, and the main iron species is ferrous oxide (wustite). Similar results were obtained for the calculated diagrams of all the other slag compositions tested in this work.

\subsubsection{X-Ray diffraction results}

The X-Ray patterns obtained at different $\mathrm{CaO} / \mathrm{SiO}_{2}$ ratios and $\mathrm{Fe} / \mathrm{SiO}_{2}=1.1$ and 1.7 are shown in the figures 2 and 3, respectively. The coexistence of wustite $\mathrm{FeO}$ (JCPD file 06-0615), franklinite $\mathrm{ZnFe}_{2} \mathrm{O}_{4}$ (JCPD file 10-0465), hardystonite $\mathrm{Ca}_{2} \mathrm{ZnSi}_{2} \mathrm{O}_{7}$ (JCPD file 12-0453), kirschsteinite $\mathrm{CaFeSiO}_{4}$ (JCPD file 11-0477), and lead silicates $\mathrm{Pb}_{4} \mathrm{SiO}_{6}, \mathrm{~Pb}_{5} \mathrm{Si}_{3} \mathrm{O}_{11}$ (JCPD files 13-0275 and 31-0692, respectively), were observed at most of the experiment conditions. Franklinite was the main iron species for the slags with $\mathrm{Fe} / \mathrm{SiO}_{2}=1.1$ and low basicity $\left(\mathrm{CaO} / \mathrm{SiO}_{2}=1.0\right.$ and 1.2); however, increasing the basicity, the amount of wustite was increased. The X-Ray patterns of figure 3 show that wustite is the main iron species for all the slags with $\mathrm{Fe} / \mathrm{SiO}_{2}=1.7$.

Zinc was in the hardystonite and franklinite species in all the slags. Figures 2 and 3 do not show peaks corresponding to metallic lead since particular attention was paid to separate entrained lead particles from the slag samples. The mineralogical species with lead found in this work were silicates $\left(\mathrm{Pb}_{4} \mathrm{SiO}_{6}, \mathrm{~Pb}_{5} \mathrm{Si}_{3} \mathrm{O}_{11}\right)$ which are in agreement with the results obtained by Calvo and Ballester ${ }^{[6]}$.

\subsection{3. $\mathrm{PbO}$ concentration in slag}

Table III shows the experimental composition for lead solubility in the slags together with the concentrations of ferrous and ferric ions.

This table shows that the ferric-to-ferrous ratios $\left(\mathrm{Fe}^{3+} / \mathrm{Fe}^{2+}\right)$ in the slags at a fixed temperature and oxygen partial pressure increases with the $\mathrm{CaO} / \mathrm{SiO}_{2}$ ratio. The experimental relationship between the concentration of lead oxide in the slag phase and the $\mathrm{CaO} / \mathrm{SiO}_{2}$ and $\mathrm{Fe} / \mathrm{SiO}_{2}$ mass ratios at $1473 \mathrm{~K}$ can be observed in figure 4 .

There is a clear tendency for the concentration of $\mathrm{PbO}$ in slag to diminish with increasing the slag basicity $\left(\mathrm{CaO} / \mathrm{SiO}_{2}\right)$ and diminishing the $\mathrm{Fe} / \mathrm{SiO}_{2}$ ratio, which is in agreement with Schesinger and Lynch ${ }^{[7]}$ who reported that by increasing the $\mathrm{CaO} / \mathrm{SiO}_{2}$ ratio reduced the $\mathrm{PbO}$ solubility in slags.

The effect of the $\mathrm{CaO} / \mathrm{SiO}_{2}$ on the $\mathrm{PbO}$ solubility can be explained by analyzing the structural behaviour of $\mathrm{CaO}$ and $\mathrm{PbO}$ in silicate slags. Both, $\mathrm{CaO}$ and $\mathrm{PbO}$, are basic oxides and produces the depolymerization of the silica network ${ }^{[13]}$; however, $\mathrm{CaO}$ is a more efficient agent to break $\mathrm{Si}-\mathrm{O}-\mathrm{Si}$ bonds. Then, in a system with high amount of $\mathrm{CaO}$, $\mathrm{PbO}$ will be free in the slag melt and its activity coefficient will be also high, then the reduction of $\mathrm{PbO}$ to give metallic lead is thermodynamically more feasible.

\subsubsection{SEM-EDS analysis}

Figure 5 shows a micrograph and the compositions obtained by SEM-EDS semi-quantitative method for 


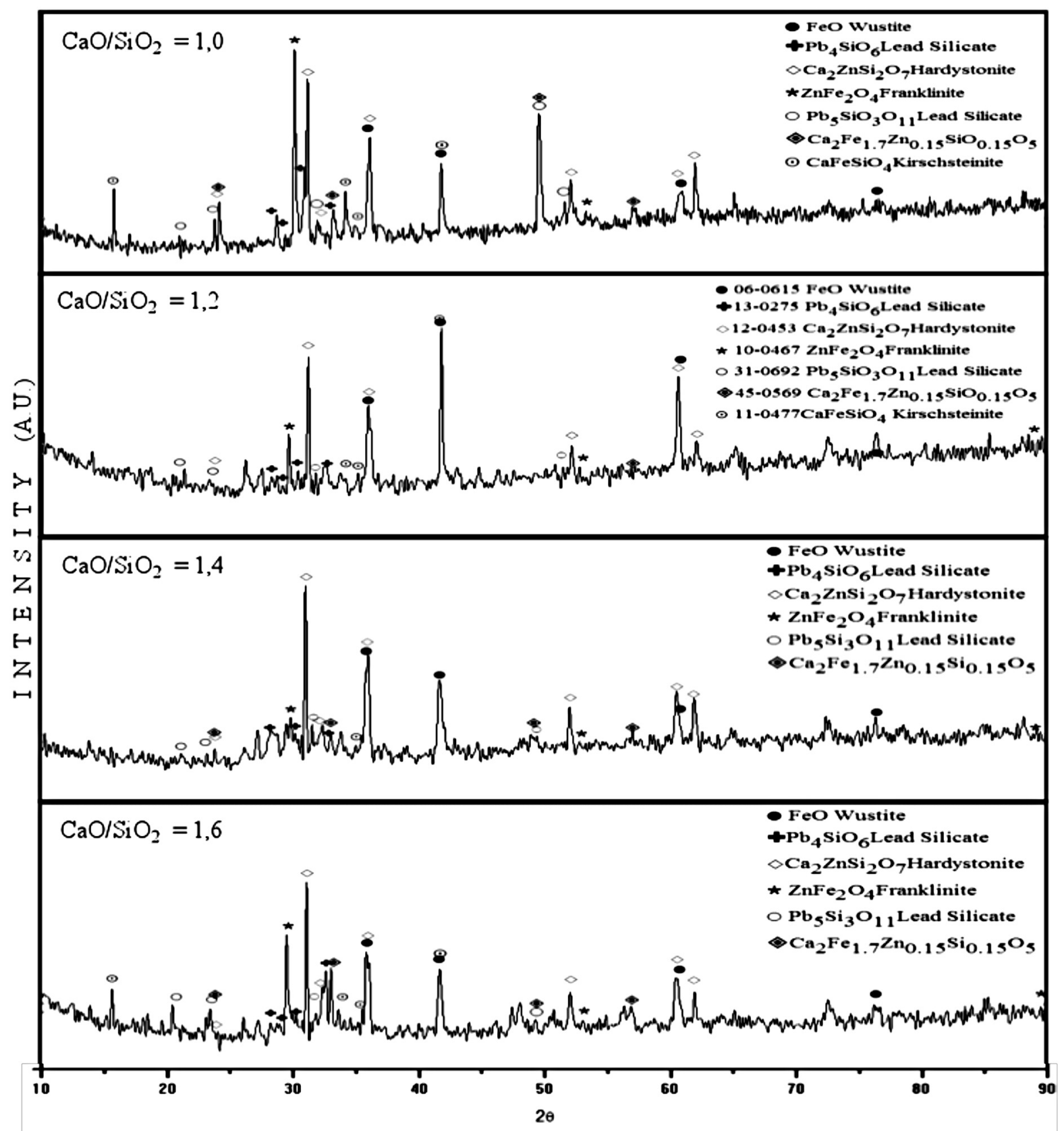

Figure 2. X-Ray patterns for slags with $\mathrm{Fe} / \mathrm{SiO} 2=1.1$ and $\mathrm{CaO} / \mathrm{SiO}_{2}=1.0 ; 1.2 ; 1.4$ and 1.6 equilibrated at $1473 \mathrm{~K}$.

Figura 2. Espectros de Rayos $X$ para escorias con $\mathrm{Fe} / \mathrm{SiO} 2=1,1$ y $\mathrm{CaO} / \mathrm{SiO}_{2}=1,0 ; 1,2 ; 1,4$ y 1,6 equilibradas a $1.473 \mathrm{~K}$.

the phases observed in the slag A-8 with $\mathrm{CaO} / \mathrm{SiO}_{2}$ $=1.6$ and $\mathrm{Fe} / \mathrm{SiO}_{2}=1.7$ (Table I).

This figure shows that a high proportion of lead, in its elemental form, is found in the slags. The metallic lead, in the form of spherical shapes, appears above a silicate matrix, in which it was not detected the metal in its oxidized form. The gray rounded particles contain mainly iron and oxygen and correspond to wustite. Irregular white particles with dark elongated crystals are also observed in figure 5; according to the EDS analysis, the white particles (labeled K) contain oxygen, silicon, calcium and iron, which might indicate that kirschsteinite $\left(\mathrm{CaFeSiO}_{4}\right)$ is present. The elongated particles contain calcium, zinc and silicon, so they probably correspond to hardystonite $\left(\mathrm{Ca}_{2} \mathrm{ZnSi}_{2} \mathrm{O}_{7}\right)$. The silicate matrix of this slag corresponds to lead silicates and franklinite $\left(\mathrm{ZnFe}_{2} \mathrm{O}_{4}\right)$, which were identified by XRD in figure 3 . 


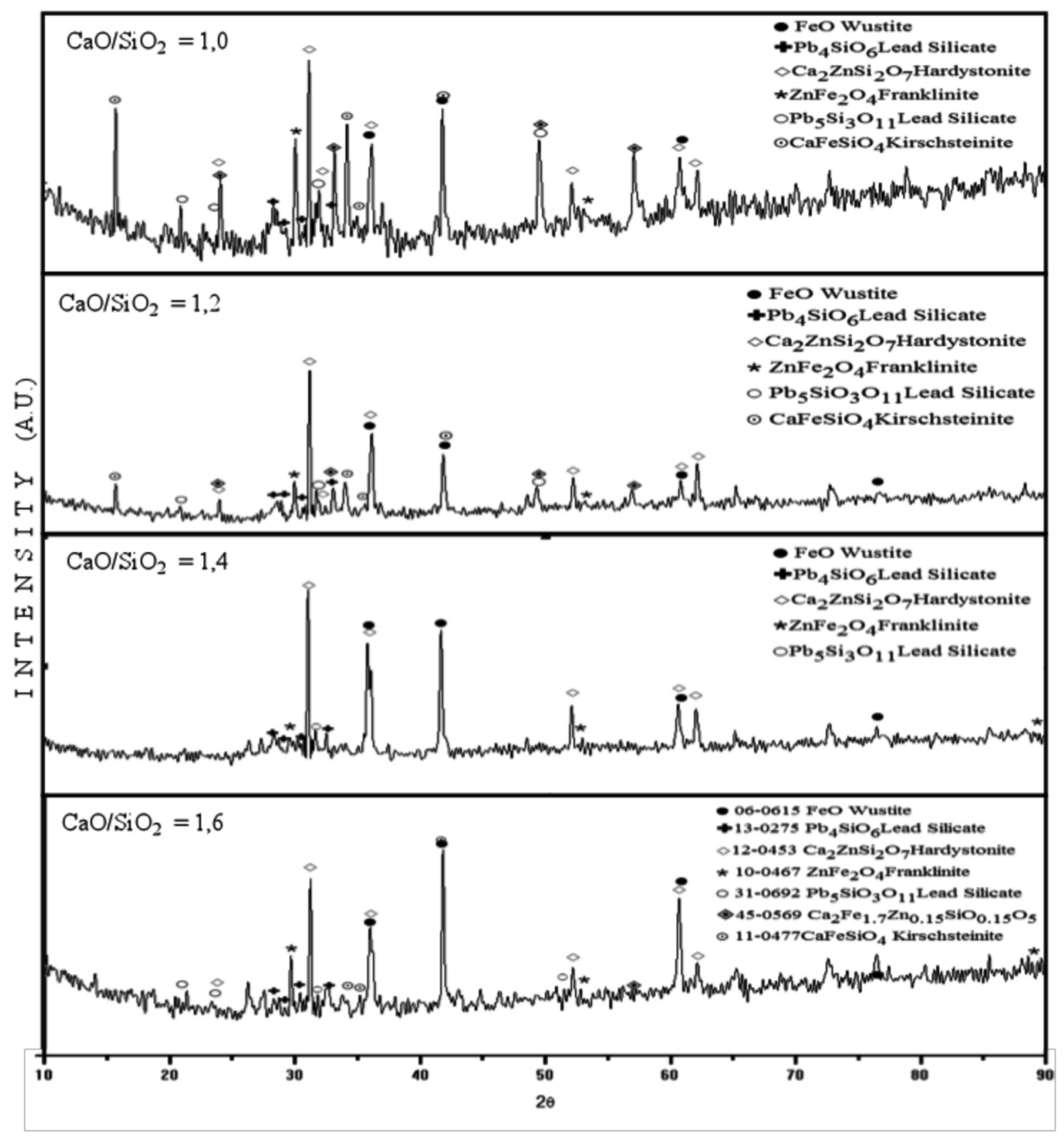

Figure 3. X-Ray patterns for slags with $\mathrm{Fe} / \mathrm{SiO}_{2}=1.7$ and $\mathrm{CaO} / \mathrm{SiO}_{2}=1.0 ; 1.2 ; 1.4$ and 1.6 equilibrated at $1473 \mathrm{~K}$.

Figura 3. Espectros de Rayos $X$ para escorias con $\mathrm{Fe} / \mathrm{SiO}_{2}=1,7$ y $\mathrm{CaO} / \mathrm{SiO}_{2}=1,0 ; 1,2 ; 1,4$ y 1,6 equilibradas a $1.473 \mathrm{~K}$.

\subsection{Second experimental part}

\subsubsection{X-Ray diffraction results}

The X-Ray patterns obtained for all the slags in the second experimental part present three species: wustite FeO (JCPD file 06-0615), kirschsteinite
$\mathrm{CaFeSiO}_{4}$ (JCPD file 11-0477), and calcium silicate $\mathrm{Ca}_{2} \mathrm{SiO}_{4}$ (JCPD file 20-0236); the amount of these three species depends on the slag composition. Figure 6 shows as example the X-Ray pattern for slag B-8 (Table II) with $\mathrm{CaO} / \mathrm{SiO}_{2}=1.6$ and $\mathrm{Fe} / \mathrm{SiO}_{2}=1.7$. The XRD method did not detected lead or silver compounds since their solubility in the slags was very low. 
Table III. Slag compositions after the equilibrium trials at $1473 \mathrm{~K}$ in a reducing atmosphere (mass \%)

Tabla III. Composición de las escorias después de las pruebas de equilibrio a $1.473 \mathrm{~K}$ bajo una atmósfera reductora (\% masa)

\begin{tabular}{lccccc}
\hline Slag & $\mathrm{CaO} / \mathrm{SiO}_{2}$ & $\% \mathrm{PbO}$ & $\% \mathrm{Fe}^{2+}$ & $\% \mathrm{Fe}^{3+}$ & $\mathrm{Fe}^{3+} / \mathrm{Fe}^{2+}$ \\
\hline A-1 & 1.0 & 18.96 & 32.10 & 1.44 & 0.044 \\
A-2 & 1.0 & 22.62 & 40.30 & 1.65 & 0.041 \\
A-3 & 1.2 & 12.80 & 32.86 & 1.49 & 0.045 \\
A-4 & 1.2 & 23.76 & 39.54 & 1.85 & 0.047 \\
A-5 & 1.4 & 16.41 & 34.69 & 1.61 & 0.046 \\
A-6 & 1.4 & 23.39 & 40.10 & 1.92 & 0.048 \\
A-7 & 1.6 & 12.34 & 30.11 & 1.89 & 0.063 \\
A-8 & 1.6 & 13.58 & 41.00 & 2.11 & 0.051 \\
\hline
\end{tabular}

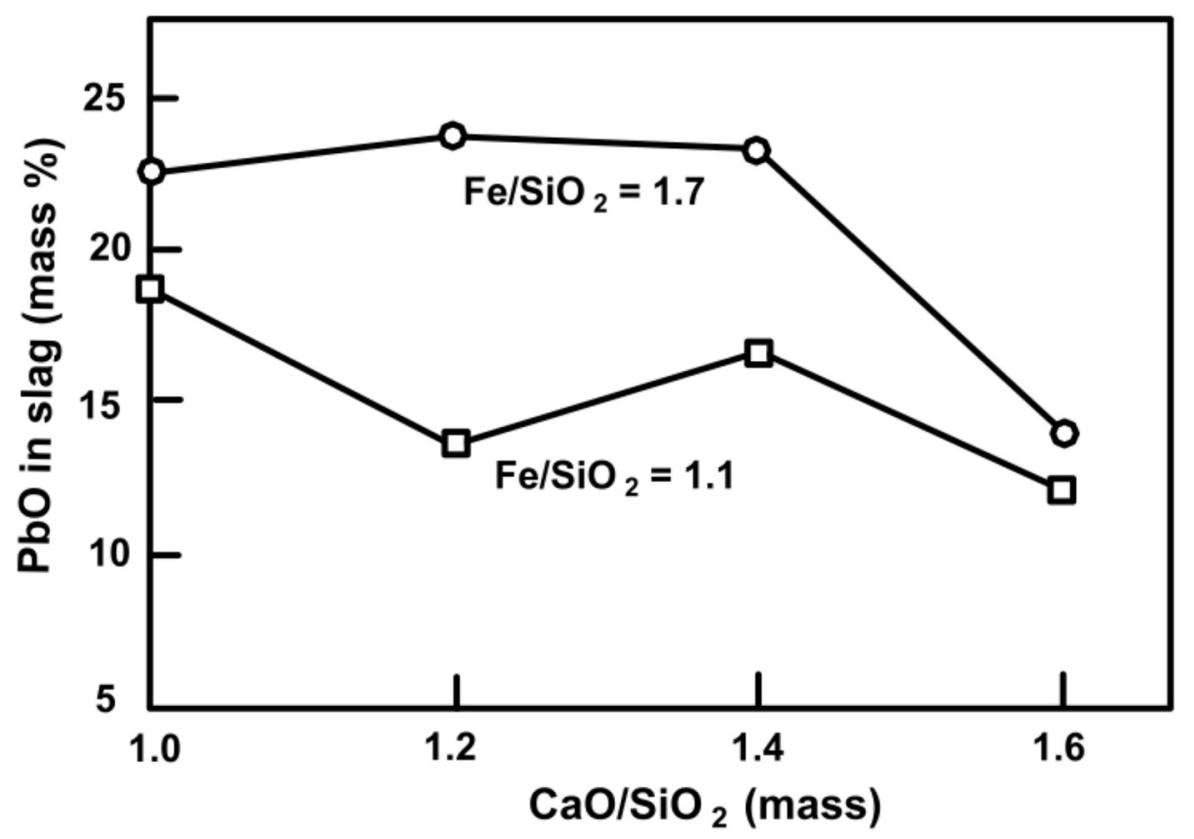

Figure 4. Effect of the $\mathrm{CaO} / \mathrm{SiO}_{2}$ and $\mathrm{Fe} / \mathrm{SiO}_{2}$ ratios on the $\mathrm{PbO}$ solubility in slags at $1473 \mathrm{~K}$ in reducing atmosphere.

Figura 4. Efecto de las relaciones $\mathrm{CaO} / \mathrm{SiO}_{2}$ y $\mathrm{Fe} / \mathrm{SiO}_{2}$ en la solubilidad de $\mathrm{PbO}$ en escorias a $1.473 \mathrm{~K}$ en atmósfera reductora.

It is worth to note that the number of species present in the slags of the second experimental part (slags B) is much lower than that of the slags of the first experimental part (slags $\mathrm{A}$ ), this is because slags$\mathrm{B}$ initially contain only 3 oxides $\left(\mathrm{CaO}, \mathrm{SiO}_{2}\right.$ and $\mathrm{Fe}_{2} \mathrm{O}_{3}$ ). The X-Ray results showed that wustite was the main iron species for all the slags because the ferric ion $\left(\mathrm{Fe}^{3+}\right)$ was reduced to ferrous ion $\left(\mathrm{Fe}^{2+}\right)$ during the experimental process since the slags were in equilibrium with a crucible of metallic iron which was a reducing agent for the ferric oxide.

\subsubsection{SEM-EDS analysis}

Figure 7 shows the micrograph and compositions obtained by SEM-EDS for the phases observed in slag B- $8\left(\mathrm{CaO} / \mathrm{SiO}_{2}=1.6\right.$ and $\left.\mathrm{Fe} / \mathrm{SiO}_{2}=1.7\right)$. 


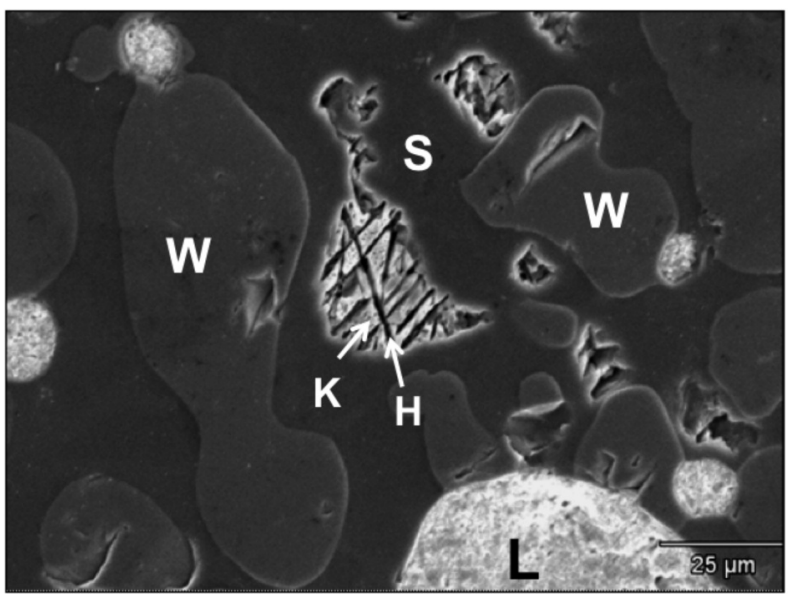

Atom \%

\begin{tabular}{|c|c|c|c|c|c|c|l|}
\hline Phase & $\mathbf{O}$ & Si & Ca & Fe & Zn & Pb & Species \\
\hline W & 7.11 & 1.22 & 0.16 & 88.0 & 0.35 & 3.16 & Wustite \\
\hline L & 1.90 & 0.91 & 0.04 & 0.35 & 0.0 & 96.8 & Metallic Pb \\
\hline H & 23.4 & 21.4 & 36.2 & 6.10 & 11.5 & 1.40 & Hardystonite \\
\hline K & 18.1 & 16.7 & 47.8 & 13.3 & 0.32 & 3.78 & Kirschsteinite \\
\hline S & 12.5 & 18.1 & 36.8 & 18.9 & 7.36 & 6.34 & $\begin{array}{l}\text { Franklinite, } \\
\text { Lead silicates }\end{array}$ \\
\hline
\end{tabular}

Figure 5. SEM micrograph and EDS analysis of the phases of the slag A-8 with $\mathrm{Fe} / \mathrm{SiO}_{2}=1.7$ and $\mathrm{CaO} / \mathrm{SiO}_{2}=1.6$ and $\mathrm{a}$ reducing atmosphere at $1473 \mathrm{~K}$.

Figura 5. Imagen de MEB y análisis EDS de las fases presentes en la escoria A-8 con $\mathrm{Fe} / \mathrm{SiO}_{2}$ $=1,7$ y CaO/ $\mathrm{SiO}_{2}=1,6$ y una atmósfera reductora a $1.473 \mathrm{~K}$.
This figure shows the three mineralogical species observed by the XRD technique. The gray rounded particles (labeled W) correspond to wustite $(\mathrm{FeO})$; irregular white particles $(\mathrm{K})$ are kirschsteinite $\left(\mathrm{CaFeSiO}_{4}\right)$ and the matrix of the slag corresponds to calcium silicate $\left(\mathrm{Ca}_{2} \mathrm{SiO}_{4}\right)$. The concentrations of lead and silver in the slags were outside the detection limit of the analytical technique of SEM-EDS.

\subsection{3. $\mathrm{PbO}$ and $\mathrm{Ag}$ in slag}

The lead oxide solubility in the $\mathrm{FeO}_{\mathrm{x}}-\mathrm{CaO}-\mathrm{SiO}_{2}$ slags at metallic iron saturation at $1473 \mathrm{~K}$ (for slags with $\mathrm{CaO} / \mathrm{SiO}_{2}=1.0$ and 1.2 ) and $1573 \mathrm{~K}$ (slags with $\mathrm{CaO} / \mathrm{SiO}_{2}=1.4$ and 1.6 ) is shown in figure 8 . The maximum lead oxide solubility is approximately 1.4 mass $\%$ in the slag with $\mathrm{CaO} / \mathrm{SiO}_{2}=1.1$, while the minimum solubility is about 0.2 mass $\%$ in the slag with $\mathrm{CaO} / \mathrm{SiO}_{2}=1.6$. Figure 8 also shows that the $\mathrm{PbO}$ solubility decreases with increasing the $\mathrm{Fe} / \mathrm{SiO}_{2}$ ratio.

The silver contents of the slags are plotted against the $\mathrm{Fe} / \mathrm{SiO}_{2}$ at different slag basicities in figure 9 .

The silver solubility in slags decreases with increasing both, $\mathrm{Fe} / \mathrm{SiO}_{2}$ and $\mathrm{CaO} / \mathrm{SiO}_{2}$ ratios. Experimental results indicated that the $\mathrm{CaO} / \mathrm{SiO}_{2}$ ratio does not have an appreciable effect on the concentration of dissolved silver in slag when this parameter is between 1.4 and 1.6; however, there is a tendency for the addition of $\mathrm{CaO}$ to reduce the concentration of silver in the slag.

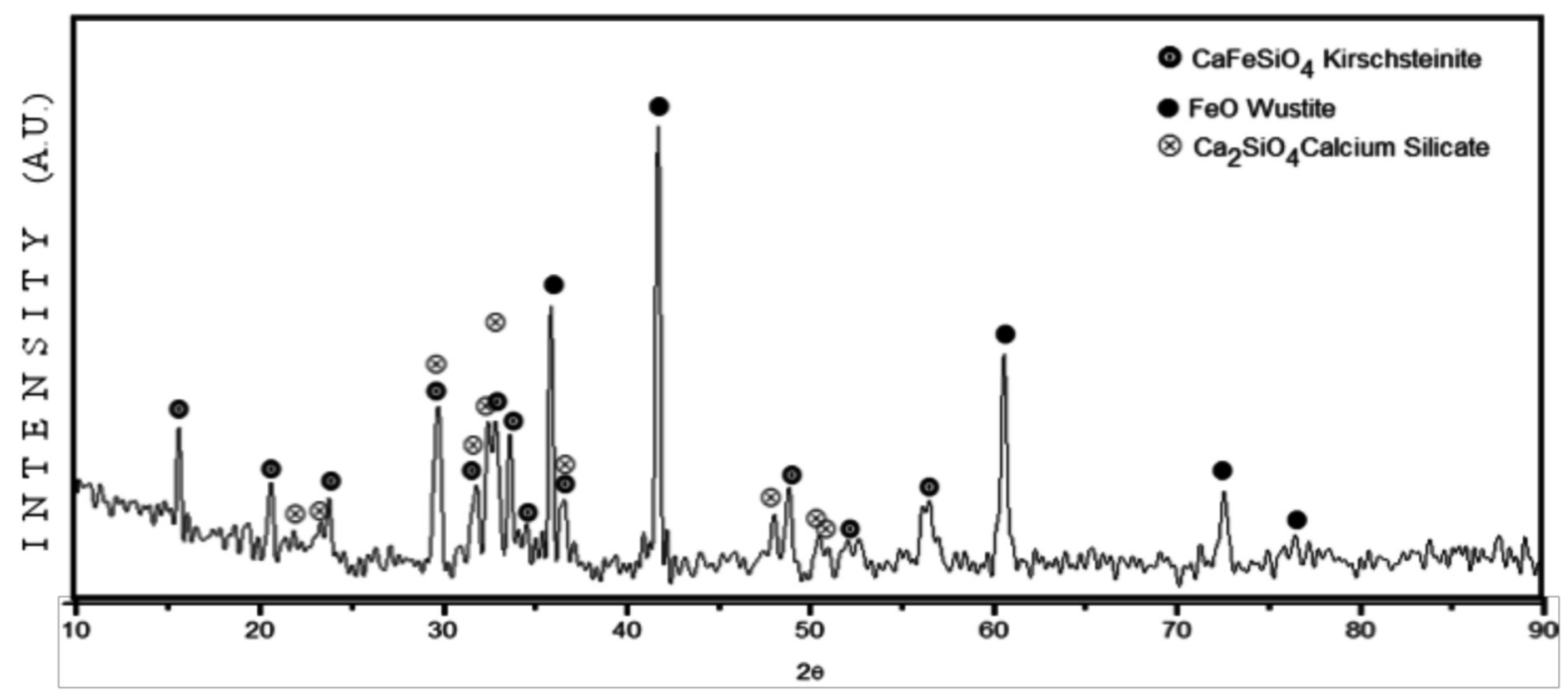

Figure 6. X-Ray pattern for the slag $\mathrm{B}-8$ with $\mathrm{Fe} / \mathrm{SiO}_{2}=1.7$ and $\mathrm{CaO} / \mathrm{SiO}_{2}=1.6$ equilibrated at 1573 in inert atmosphere.

Figura 6. Espectro de Rayos $X$ para la escoria $\mathrm{B}-8$ con $\mathrm{Fe} / \mathrm{SiO}_{2}=1,7$ y $\mathrm{CaO} / \mathrm{SiO}_{2}=1,6$ equilibrada a $1.573 \mathrm{~K}$ en atmósfera inerte. 


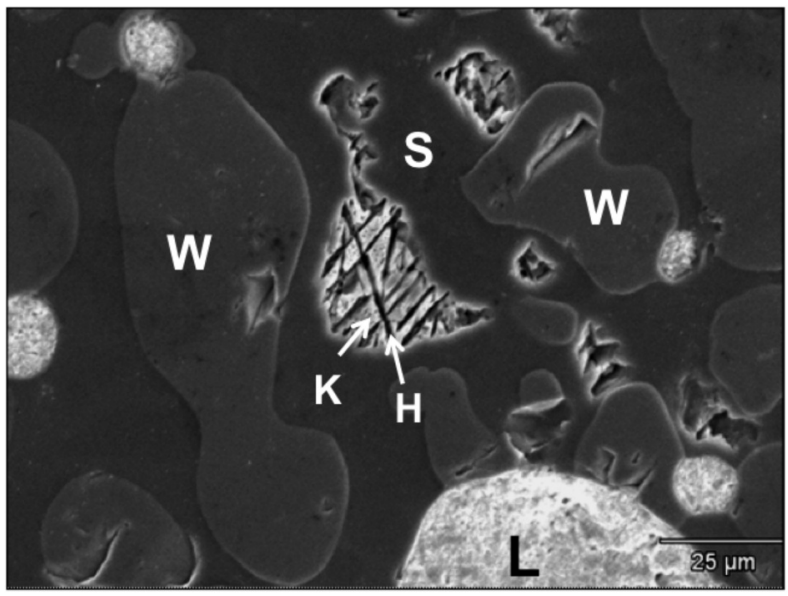

Atom \%

\begin{tabular}{|c|c|c|c|c|c|c|l|}
\hline Phase & $\mathbf{O}$ & $\mathbf{S i}$ & $\mathbf{C a}$ & $\mathbf{F e}$ & $\mathrm{Zn}$ & $\mathbf{P b}$ & Species \\
\hline W & 7.11 & 1.22 & 0.16 & 88.0 & 0.35 & 3.16 & Wustite \\
\hline L & 1.90 & 0.91 & 0.04 & 0.35 & 0.0 & 96.8 & Metallic Pb \\
\hline H & 23.4 & 21.4 & 36.2 & 6.10 & 11.5 & 1.40 & Hardystonite \\
\hline K & 18.1 & 16.7 & 47.8 & 13.3 & 0.32 & 3.78 & Kirschsteinite \\
\hline S & 12.5 & 18.1 & 36.8 & 18.9 & 7.36 & 6.34 & $\begin{array}{l}\text { Franklinite, } \\
\text { Lead silic ates }\end{array}$ \\
\hline
\end{tabular}

Figure 7. SEM micrograph and EDS analysis of the phases of the slag B-8 with $\mathrm{Fe} / \mathrm{SiO}_{2}=1.7$ and $\mathrm{CaO} / \mathrm{SiO}_{2}=1.6$ and an inert atmosphere at $1573 \mathrm{~K}$.

Figura 7. Imagen de MEB y análisis EDS de las fases presentes en la escoria $B-8$ con $\mathrm{Fe} / \mathrm{SiO}_{2}=1,7$ y $\mathrm{CaO} / \mathrm{SiO}_{2}=1,6$ y una atmósfera inerte a $1.573 \mathrm{~K}$.

\section{CONCLUSIONS}

- Two experimental studies of metal solubility in slags were carried out at $1473 \mathrm{~K}$ and $1573 \mathrm{~K}$. In the first experimental part the solubility of lead oxide in the $\mathrm{PbO}-\mathrm{ZnO}-\mathrm{CaO}-\mathrm{SiO}_{2}-\mathrm{Fe}_{2} \mathrm{O}_{3}$ " slag system under a reducing atmosphere was studied. In the second part, slags of the $\mathrm{CaO}$ $\mathrm{SiO}_{2}-$ " $\mathrm{Fe}_{2} \mathrm{O}_{3}$ " system were equilibrated with $\mathrm{Pb}$ - 1.3 mass \% Ag alloys under an inert atmosphere. The following conclusions were obtained:

- Lead oxide solubility in the slags diminishes with increasing the slag basicity $\left(\mathrm{CaO} / \mathrm{SiO}_{2}\right)$ and diminishing the $\mathrm{Fe} / \mathrm{SiO}_{2}$ ratio in slags of the $\mathrm{PbO}$ $\mathrm{ZnO}-\mathrm{CaO}-\mathrm{SiO}_{2}-$ - $\mathrm{Fe}_{2} \mathrm{O}_{3}$ " system under reducing atmosphere.

- Lead oxide and silver solubility in slags decrease with increasing both $\mathrm{CaO} / \mathrm{SiO}_{2}$ and $\mathrm{Fe} / \mathrm{SiO}_{2}$

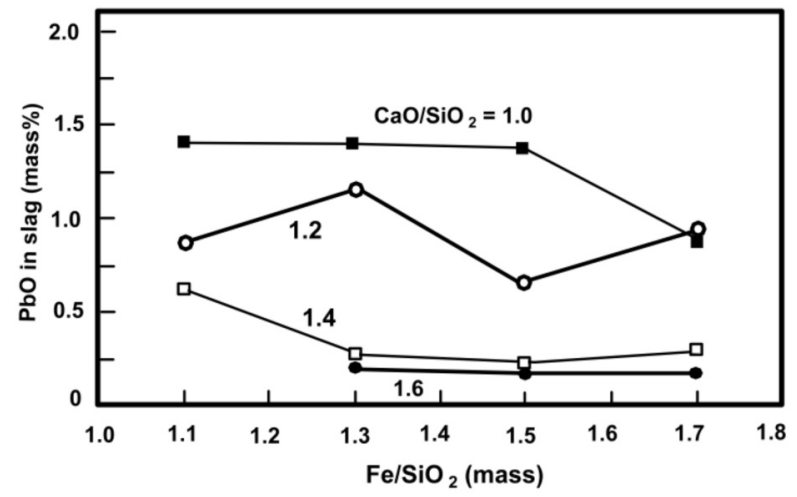

Figure 8. Lead oxide solubility in the slag as a function of $\mathrm{CaO} / \mathrm{SiO}_{2}$ and $\mathrm{Fe} / \mathrm{SiO}_{2}$ mass ratios at $1473 \mathrm{~K}$ and $1573 \mathrm{~K}$.

Figura 8. Solubilidad del óxido de plomo en la escoria en función de las relaciones $\mathrm{CaO} / \mathrm{SiO}_{2}$ y $\mathrm{Fe} / \mathrm{SiO}_{2}$ a $1.473 \mathrm{~K}$ y $1.573 \mathrm{~K}$.

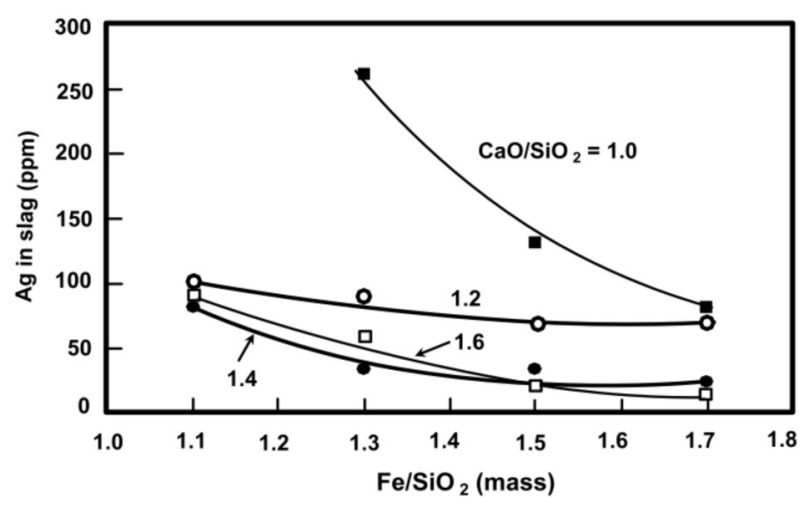

Figure 9. Silver solubility in the slag as a function of $\mathrm{CaO} / \mathrm{SiO}_{2}$ and $\mathrm{Fe} / \mathrm{SiO}_{2}$ mass ratio at 1473 $\mathrm{K}$ and $1573 \mathrm{~K}$.

Figura 9. Solubilidad de la plata en la escoria en función de las relaciones $\mathrm{CaO} / \mathrm{SiO}_{2}$ y $\mathrm{Fe} / \mathrm{SiO}_{2}$ a $1.473 \mathrm{~K}$ y $1.573 \mathrm{~K}$.

ratios in the slags of the $\mathrm{CaO}-\mathrm{SiO}_{2}-" \mathrm{Fe}_{2} \mathrm{O}_{3}$ " system under an inert atmosphere

- Lead oxide was the only compound that could be reduced under the reducing atmosphere $\left(\mathrm{P}_{\mathrm{CO}} / \mathrm{P}_{\mathrm{CO} 2}=2.45\right)$ and at the temperature at the blast furnace tuyeres level (1473 K), reported in the literature. The main iron species under these conditions was wustite $(\mathrm{FeO})$.

- Wustite $(\mathrm{FeO})$, franklinite $\left(\mathrm{ZnFe}_{2} \mathrm{O}_{4}\right)$, hardystonite $\left(\mathrm{Ca}_{2} \mathrm{ZnSi}_{2} \mathrm{O}_{7}\right)$ kirschsteinite $\left(\mathrm{CaFeSiO}_{4}\right)$ and lead silicates $\left(\mathrm{Pb}_{4} \mathrm{SiO}_{6}\right.$, $\left.\mathrm{Pb}_{5} \mathrm{Si}_{3} \mathrm{O}_{11}\right)$ were the main species obtained in the slags of the $\mathrm{PbO}-\mathrm{ZnO}-\mathrm{CaO}-\mathrm{SiO}_{2}-" \mathrm{Fe}_{2} \mathrm{O}_{3}$ " system 
under the reducing atmosphere at $1473 \mathrm{~K}$. Whereas wustite, kirschsteinite and calcium silicate $\left(\mathrm{Ca}_{2} \mathrm{SiO}_{4}\right)$ were obtained in the slags of the $\mathrm{CaO}-\mathrm{SiO}_{2}-" \mathrm{Fe}_{2} \mathrm{O}_{3}$ " system under inert atmosphere at $1473 \mathrm{~K}$ and $1573 \mathrm{~K}$.

\section{ACKNOWLEDGEMENTS}

The authors thank Servicios Administrativos Peñoles S.A. de C.V. for providing financial support for this project. The authors wish also to thank the Institutions CONACyT, COFAA and IPN for their permanent assistance to the Process Metallurgy Group at ESIQIE-Department of Metallurgical Eng.

\section{REFERENCES}

[1] P. C. Hayes, M. E. Schlesinger, H-U. Steil and A. Siegmund, Lead-Zinc 2010 Conference, Vancouver, Canada (ed: A. Siegmund, L. Centomo, C. Geenen, N. Piret, G. Richards and R. Stephens) (TMS) 2010, pp. 345-355.

[2] J. Sancho, L. F. Verdeja and A. Ballester, Metalurgia Extractiva: Procesos de Obtención. Ed. Síntesis, Madrid, España, 2000, pp. 377 404.

[3] A. Ballester, L. F. Verdeja and J. Sancho, Metalurgia Extractiva: Fundamentos. Ed. Síntesis, Madrid, España, 2000, pp. 267-284.
[4] E. Jak and P. C. Hayes, Lead-Zinc 2010 Conference, Vancouver, Canada (ed: A. Siegmund, L. Centomo, C. Geenen, N. Piret, G. Richards and R. Stephens) (TMS) 2010, pp. 1161-1176.

[5] P. Tan and P. A. Vix, EPD Congress 2005, San Francisco, California, USA (ed: M. Schlesinger) (TMS) 2005, pp. 329-338.

[6] F. A. Calvo and A. Ballester, Metall. Mater. Trans. B, 17B (1986) 267-270.

[7] M. E. Schlesinger and D. C. Lynch, Metall. Mater. Trans. B, 17B (1986) 817-827.

[8] M. Kudo, E. Jak, P. Hayes, K. Yagamuchi and Y. Takeda, Metall. Mater. Trans. B, 31B (2000) 15-24.

[9] H. M. Henao, P. C. Hayes, E. Jak and G. G. Richards, Lead-Zinc 2010 Conference, Vancouver, Canada (Eds: A. Siegmund, L. Centomo, C. Geenen, N. Piret, G. Richards and R. Stephens) 2010, pp. 1145-1160.

[10] D. R. Morris, B. R. Amero, P. G. Evans, W. Petruk and D. R. Owens, Metall. Mater. Trans. B, 14B (1983) 617-623.

[11] J. T. Chao, P. J. Dugdale, D. R. Morris and F. R. Steward, Metall. Mater. Trans. B, 9B(1978) 293-300.

[12] W. T. Thompson, C. W. Bale and A. D. Pelton, Facility for the Analysis of Chemical Thermodynamics (FACTSage), Ecole Polytechnique, Montreal, 2011, http:www.crct.polymtl.ca.

[13] A. Romero-Serrano and A. D. Pelton, Metall. Mater. Trans. B, 26B (1995) 305-315. 